\title{
Article \\ Critical Minerals from Post-Processing Tailing. A Case Study from Bangka Island, Indonesia
}

\author{
Karol Zglinicki ${ }^{1, *(D)}$, Krzysztof Szamałek ${ }^{1,2}$ and Stanisław Wołkowicz ${ }^{1}$ \\ 1 Polish Geological Institute-National Research Institute, 00-975 Warsaw, Poland; \\ krzysztof.szamalek@pgi.gov.pl (K.S.); stanislaw.wolkowicz@pgi.gov.pl (S.W.) \\ 2 Faculty of Geology, University of Warsaw, 02-089 Warsaw, Poland \\ * Correspondence: karol.zglinicki@pgi.gov.pl
}

Citation: Zglinicki, K.; Szamałek, K.; Wołkowicz, S. Critical Minerals from Post-Processing Tailing. A Case Study from Bangka Island, Indonesia. Minerals 2021, 11, 352. https:// doi.org/10.3390/min11040352

Academic Editors:

George Angelopoulos and Luis Pérez Villarejo

Received: 3 March 2021

Accepted: 26 March 2021

Published: 28 March 2021

Publisher's Note: MDPI stays neutral with regard to jurisdictional claims in published maps and institutional affiliations.

Copyright: (C) 2021 by the authors. Licensee MDPI, Basel, Switzerland. This article is an open access article distributed under the terms and conditions of the Creative Commons Attribution (CC BY) license (https:/ / creativecommons.org/licenses/by/ $4.0 /)$.

\begin{abstract}
The growing demand for critical raw materials (rare earth elements- $\mathrm{REE}, \mathrm{Nb}, \mathrm{Ta}$, and others) enforces a need to look for their alternative sources. Distortions of the mineral supply chain caused by COVID-19 have necessitated a re-evaluation of what exists as mining waste from previous exploitation. Consequently, this study aims to provide an inventory of raw materials on the Indonesian Tin Islands (Bangka and Belitung). Geological and mineralogical examinations on Bangka have permitted an economic appraisal of tailings from the processing of cassiterite-bearing sands and confirmed the presence of REE-bearing minerals, chiefly monazite and xenotime, zircon, ilmenite, rutile, niobium-tantalum phases. In general, the mineral content of the tailings varies depending on the sampling site and the type of processing used during ore-production. ICP-MS (inductively coupled plasma-mass spectrometers) analyses revealed anomalous concentrations of LREE (light rare earth elements): $\mathrm{La}>5 \%, \mathrm{Ce}>5 \%, \mathrm{Pr}>1 \%, \mathrm{Nd}>1 \%, \mathrm{Sm}>1 \%$ and HREE $+\mathrm{Y}$ (heavy rare earth elements and yttrium) up to $2.51 \mathrm{wt} \%$. High values have been found for the "most critical" metals of the HREE group: Dy (up to $0.34 \mathrm{wt} \%$ ), Tb (up to $0.08 \mathrm{wt} \%$ ), Eu (up to $61.8 \mathrm{ppm}$ ), $\mathrm{Nd}$ $(>1.0 \mathrm{wt} \%$ ), and $\mathrm{Y}$ (up to $1.20 \mathrm{wt} \%$ ). In addition, the following contents have been defined: Ga (to $0.03 \mathrm{wt} \%$ ); Hf (to $0.64 \mathrm{wt} \%$ ); Ta (to $0.08 \mathrm{wt} \%$ ); $\mathrm{Nb}$ (to $0.23 \mathrm{wt} \%$ ); $\mathrm{W}$ (to $0.14 \mathrm{wt} \%$ ); $\mathrm{Zr}$ (>5.0 wt $\%$ ); and Sc (to $0.01 \mathrm{wt} \%$ ). Such high concentrations suggest the tailing dumps to be a potential new source of "critical raw materials".
\end{abstract}

Keywords: mineral waste; critical raw materials; monazite and xenotime; REE

\section{Introduction}

In the global modern economy, metals used in high technology and advanced industry play an increasingly important role [1-3]. In the geological literature, they are referred to as critical, strategic, or pivotal metals [4]. Countries where these are in demand strive to gain access to the necessary amounts of high-quality resources ensuring their mineral security [3]. Every three years, the European Commission issues a list of raw materials of key importance for the community economy [5-8]. There are new European challenges, such as the European Green Deal which requires member countries to reduce their greenhouse gas emission $50-55 \%$ by 2030 [9].

The occurrence of the majority of known critical raw material is restricted to only a few areas on the planet. Good examples are Co and Ta supplied to the European market mainly from the Democratic Republic of Congo (in 68\% and 36\%, respectively) [8]. Monopolistic China is responsible for fully 99\% LREE and 98\% HREE supply to the European Union (EU) [8].

The European Commission together with the association of European Geological Surveys EuroGeoSurveys [10] have proposed a reinventory of Europe's economic geopotential, particularly with regard to deep geological structures, a more effective use of recycled material, and more detailed investigations of the mineral potential of the seas surrounding the European continent. Theoretically, it is a sound approach, but in practice it proves 
to be rather time-consuming. A number of EU member countries are instead conducting fairly intensive geological reconnaissance surveys on other continents. Europe's economic progress necessitates a steady and continuous supply of critical raw materials. The lack of substitutes for most critical raw materials, the limited number of known deposits, and difficult access to those recognized but yet-to-be developed causes the necessity to ensure steady supplies from outside the European Union [3]. All this will lead to big competition on the global commodity market and the restoration of the global economy after COVID-19 pandemia will most certainly entail implementation of numerous projects related to mineral resources world-wide. Moreover, the distortion of global supply chains and the unstable situation on the commodity market will inevitably enforce a search for alternative critical minerals sources $[1,11]$. The limited supply chain of critical raw materials requires actions for sustainability by increasing recycling efficiency and searching for substitutes of metals (Co, Nb, W, REE, and other). Difficulties in the access to critical raw materials for industrial sectors vitally force the search for alternatives to these metals [12]. To this end, efforts are underway for the European Union to become a leader in the alternative use of raw materials by 2050. Mineral security is increasingly becoming a priority for safe economic development.

The growing demand of critical raw materials coupled with a gradual exhaustion of high-quality ore resources creates the need to evaluate the potential of existing mining wastes and to initiate use of materials recovered from urban mining. Quite frequently, mining waste subjected to recycling already proved to be the source of some metals (REE, $\mathrm{Co}, \mathrm{Re}, \mathrm{Li}$ ) and in the near future, it will most probably grow in significance. Until now, for economic and/or technological reasons, such sources have largely been ignored. However, improvements in modern recovery technologies now enable an economically-effective extraction of raw materials from waste rocks. A proven way of increasing the supply of critical raw materials is the processing of tailings generated during mining of cassiteritebearing sands on the Indonesian Islands of Bangka, Beilitung, and Singkep [11].

Currently, it is estimated that 80 to 90 billion tons of waste rock and 5 to 8 billion tons of tailings stored world-wide on dumping piles and in post-flotation settling ponds are produced annually [13]. The recovery of minerals from tailings demands technological facilities for the exploitation of waste ore, waste rock, and post-flotation waste as in the nearest future, the amount of mining waste will grow with the recovery of lower and lower grade ores.

Obviously, dumps of mine waste have a devastating and usually long-term effect on the local natural environment. Apart from the space they take up, which could be used more effectively and instability of the bedrock, they are responsible for harmful fumes, toxic gas exhaustion, dust-creation, acid mine drainage into groundwater [14]. Some authors worked on recovery of raw materials from mining wastes and tailings and the associated mitigation of environmental impacts [15-17]. The evaluation of the mineral potential of mining waste lies in agreement with the concept of the circular economy, sound use of resources, and reduction of the negative impact on the natural environment. Both, dumping sites and settling ponds, may provide valuable sources of many metals. Waste recycling is the key target in both the circular economy concept and the zero-waste philosophy.

For the last several years in Indonesia, a team of Polish geologists have been evidencing and examining dumping sites and tailings generated by ongoing mining operations. This project initiated in 2013 on Bangka Island and includes mineralogical and chemical examinations of tailings and is focused on critical metals needed by the EU. Field investigations have resulted in the collection of 35 samples of tailings generated from the processing of cassiterite-bearing sands and have provided data on both the production and potential resources of the waste material. In this article, are presented new data on contents of critical minerals (Ti, Nb, Ta, REE, W, Ga, Hf, Zr, Sc) in tailings from Bangka Island, complementary to those not reported in the previous publication [11]. 


\section{Geological Setting}

Bangka Island (Figure 1) lies in the southern continuation of the Southeast Asian Tin Belt extending from Myanmar and Thailand through the Malaysian Peninsula to the Indonesian islands $[18,19]$. Its geological evolution was related to subduction and accretion of the "Sibusmasu" islands arches (China-Siam-Burma-Malaysia-Sumatra acronym) to the Indochina terranes during the closure of Palaeotethys from the turn of the Devonian to the Middle Triassic and of the Neotethys from the Permian to the Palaeogene [20,21]. These tectonic events have been responsible for the formation of three granite provinces which differ both in geochemical and petrological characteristics [19,22]: (1) The West Granite Province with Cretaceous granites of type S and I; (2) The East Granite Province with Permo-Triassic granites of type I; and (3) The Central Granite Province with predominantly Triassic granites of type S.

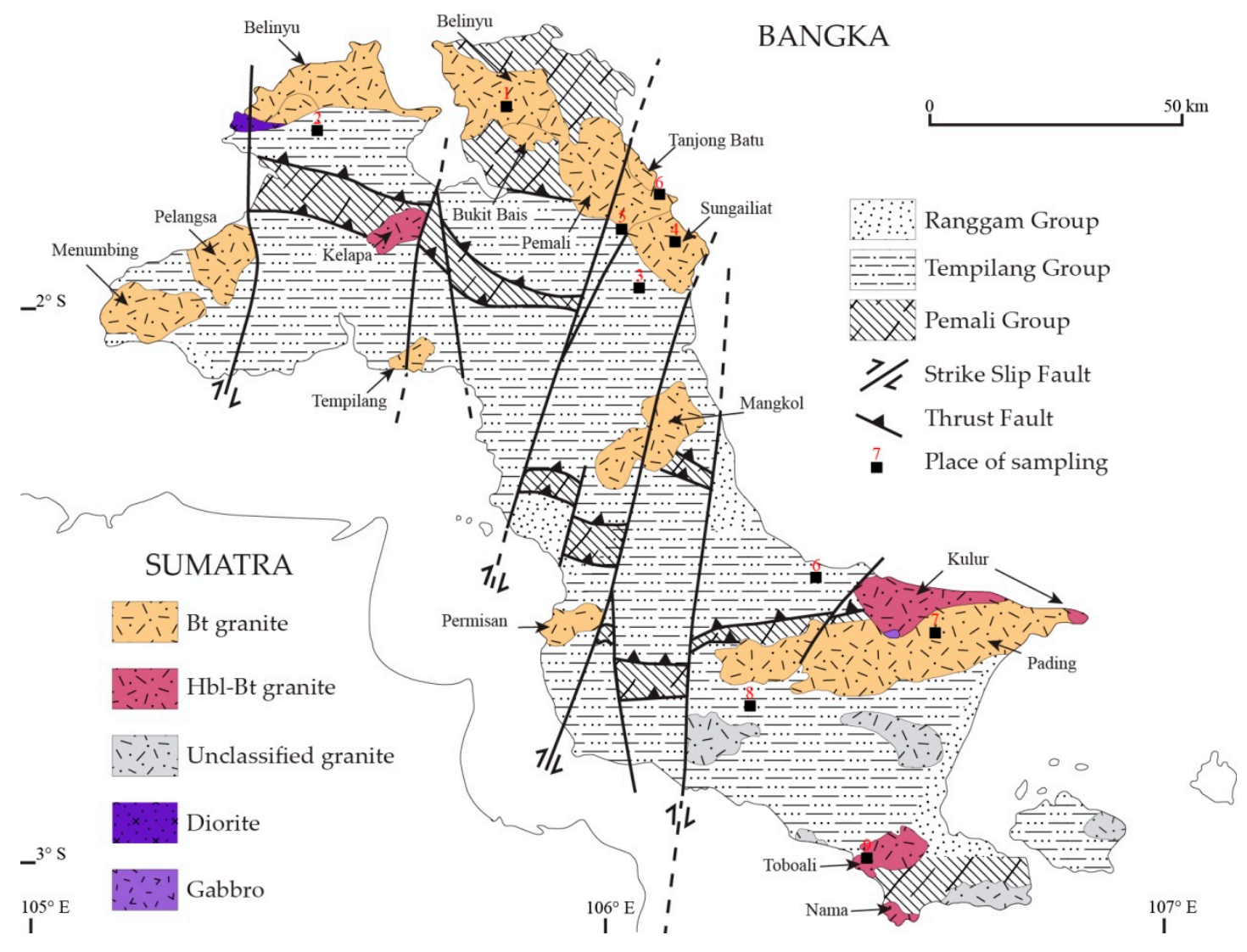

Figure 1. Geological map of Bangka Island (modified from [19,23-25]).

The age of the granitic plutons on the Indonesian Tin Islands is estimated at $197 \pm 12$ to $252 \pm 12 \mathrm{Ma}[21,23]$. U-Pb datings [24] of zircons indicate that granites known from the north eastern and south western part of the Bangka Island were formed respectively at ca. $225 \mathrm{Ma}$, and ca. $220 \mathrm{Ma}$ in the course of two magmatic episodes. The Indonesian granites are the southern continuation of the Main Range granite provinces [24].

Two main and 13 smaller magmatic batholiths from the island are known to have intruded the country rock at the turn of the Permian and Triassic. The plutons are very variable, their composition ranges from gabbros to granites [18,23,25-28]. Among the granitoid structures, the following granite varieties have been distinguished: biotitic, hornblendebiotite, two-mica, pegmatitic and pegmatite, and aplite in lenticular form $[18,19]$. The Bangka granites are classified to the ilmenite-series granites [29]. Metasomatic and hydrothermal processes were closely related to the granitic magmatism and were responsible for the origination of the rich primary tin mineralization [18]. Granitic rocks have been 
subjected to very intensive chemical weathering under tropical conditions which persisted throughout the Neogene until the present, their weathering products developed as kaolin covers, placers, and off- and on-shore deposits being extensions of the overflooded palaeovalleys [19].

\section{Materials and Methods}

\subsection{Sampling}

In 2013, in the course prospecting on Bangka Island, 35 residuals left after postprocessing of cassiterite-bearing sands were sampled [11]. Regardless of the source of the cassiterite-bearing sands, each process consists of 2 stages of mineral processing. The initial separation process is carried out by miners in the mines using the wooden washing cradles. The pre-tailing obtained initially process is brought in by compradors, where another separation process takes place using shaking table [11]. The material was acquired from manufacturers/vendors of the commodity (compradors) derived from adjacent stockyards adjacent to their dwelling places and located close to the following localities (marked by numbers): 1-Belinyu, 2-Puput (West Bangka Regency); 3-Jurung, 4-Sungai Liat, 5-Pemali, 6-Matras (Bangka Regency), 7-Lubuk (Central Bangka); 8-Nyelanding, 9-Toboali (South Bangka Regency). Samples were taken from jute sacks using a $30 \mathrm{~cm}$ long PVC (polyvinyl chloride) sampler $3 \mathrm{~cm}$ in diameter. In order to ensure the representativeness of the samples, one sample shall consist of 12 subsamples taken from 12 bags. The subsample was taken from three levels (bottom/middle/top) of every sack so as to avoid anthropogenic hypoconcentration. Subsequently, the samples were mixed using the ring and cone method and minimized in a Jones apparatus. From 9 tailing stockyards, a total of 35 clastic, each approximately $2 \mathrm{~kg}$ in weight.

\subsection{Analytical Methods}

\subsubsection{Grain Size Distribution}

Nylon sieves of 2.0 to 0.063 mm MESH (Laboratory of Clay Raw Materials, Faculty of Geology, University of Warsaw, Warsaw, Poland)) were used for gravitational separation of the material according to the Wenthworth classification (1922) [30] and, for the statistical analysis, the open source GRADISTAT v.5.11 [31] (Laboratory of Clay Raw Materials, Faculty of Geology, University of Warsaw, Warsaw, Poland) and a logarithmic method was applied.

\subsubsection{X-ray Diffraction}

The phase composition was examined using the X'Pert PRO MPD (PANalytical B.V., The Netherlands) diffractometer, in the Bragg-Brentano focusing geometry. Diffractograms were recorded in the $4-90^{\circ} 2 \theta$ angle range, with $0.026^{\circ} 2 \theta$ measurement step and rotation $1 / 2 \mathrm{~s}$, in filtered $\mathrm{CoK} \alpha$ (filter Fe) radiation of $30 \mathrm{~mA}$ and $40 \mathrm{kV}$. The instrument is equipped with a solid-state PIXcel detector for recording XRD spectra. Measurement time was $3 \mathrm{~h}$. Crystalline phases were identified using the X'Pert HighScore Plus software by comparing the registered diffractograms with the ICDD PDF-2-4+ standards.

\subsubsection{Microscopic Observations}

A total of 35 standard thin sections were prepared, one for each sample. Observations (SEM-BSE) have been conducted under the FE-SIGMA VP (Carl Zeiss Microscopy Ltd., Cambridge, UK) scanning microscope equipped with two detectors EDS (SDD XFlash $\mid$ 10) (Bruker, Germany). Analytical conditions were an accelerating voltage of $25 \mathrm{kV}$ in a high vacuum. The samples were dusted with thin carbon film. XRD and SEM-BSE examinations were completed at the Faculty of Geology, University of Warsaw.

\subsubsection{Chemical Composition}

The chemical composition was determined by the certified laboratory (ISO9001:2008) ACME Labs in Vancouver (Canada) using the LF202 and AQ200 (code) analysis programs 
(www.acmelab.com, accessed on 10 March 2021). An approximately $10 \mathrm{~g}$ sample was ground, and $3 \mathrm{~g}$ sample was mixed with sodium lithium borate $\left(\mathrm{Na}_{2} \mathrm{~B}_{4} \mathrm{O}_{7} / \mathrm{Li}_{2} \mathrm{~B}_{4} \mathrm{O}\right)$, and subsequently diluted in a mixture of aggressive acids. Owing to the presence of meltresistant phases, the PF370 (sodium peroxide fusion for refractory mineral ores) method had to be introduced. The metal content was determined by the ICP-MS/ES method. Information on the level of accuracy and analytical precision can be found on (www. acmelab.com, accessed on 10 March 2021). Loss on ignition (LOI) was calculated by weight difference after ignition at $1000^{\circ}$. Additionally, the TOT/S (total sulfur) and TOT/C (total carbon) contents were determined using the LECO organic analyzer.

\section{Results}

\subsection{Grain Size and Macroscopic Description of Tailings Samples}

The grain size analysis revealed the tailings to be equivalents of fine-grained sands (27 samples) with medium to good sorting degree, the predominating grain fraction falling between 0.1 and $0.25 \mathrm{~mm}$ (Figure 2A,C,D). Statistical parameters are indicative of differentiated skewness coefficients: platykurtic, mezokurtic, and leptokurtic as well as a variable kurtosis. The remainder 8 samples correspond to medium-grained sands with a poor or medium sorting degree, platykurtic and mezokurtic, fine and coarse skewed. The predominant grain fraction lies in the 0.25 to $0.5 \mathrm{~mm}$ range (Figure 2B).

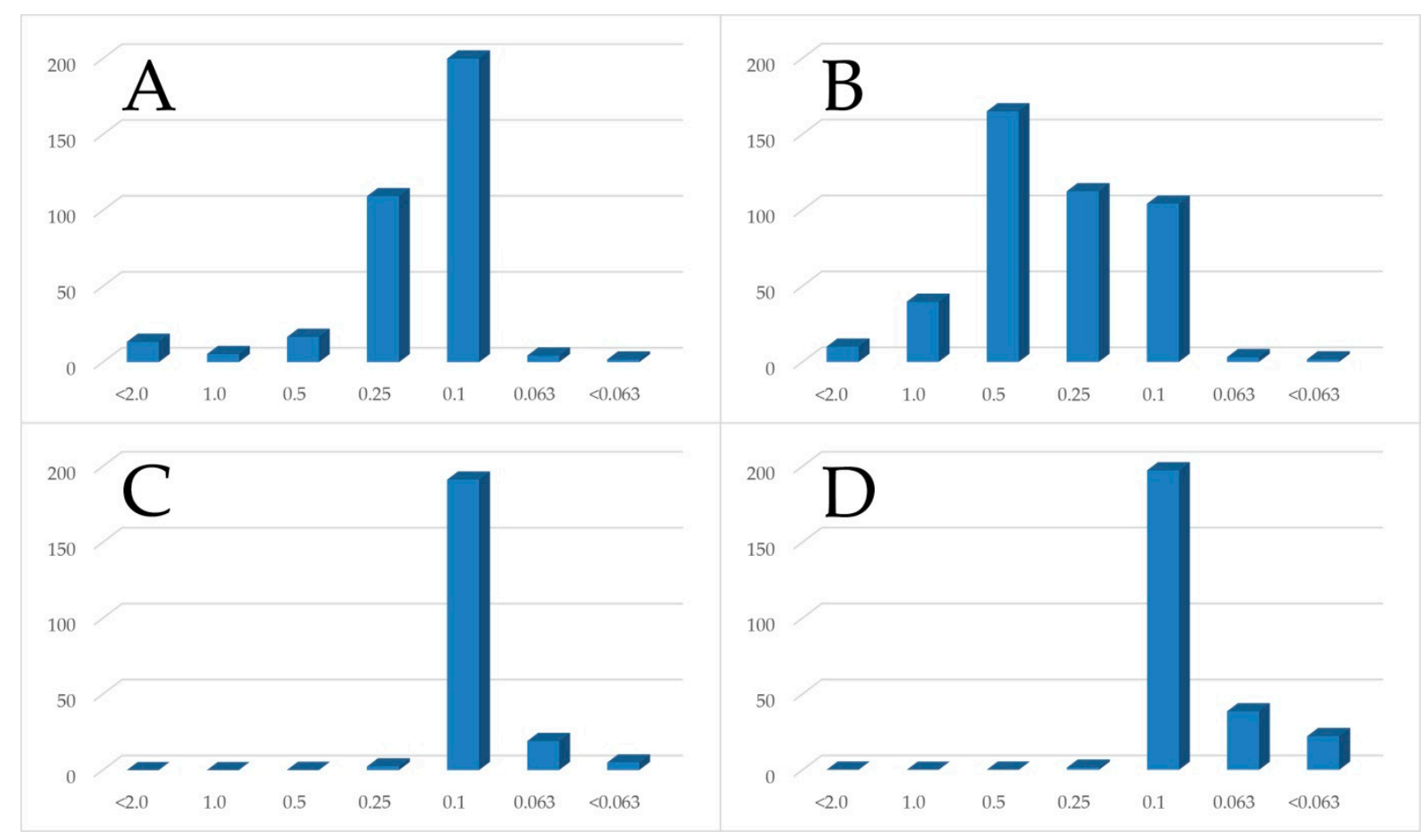

Figure 2. Grain size distribution in tailing samples in mm; (A) fine-grained, medium-sorted tailing from Toboali; (B) medium-sorted, poorly sorted tailing from Lubuk; (C) fine-grained, well-sorted tailing from Pemali; (D) fine-grained, medium-sorted tailing from Sungai Liat.

Depending on the predominating mineral constituent, the samples show the following colors: (1) black; (2) mottled white-black (Figure 3A); (3) pink (Figure 3B); (4) mottled orange-black; and (5) mottled yellow-black. Rock fragments and organic matter (leaf and bark remains) are absent. The appearing yellow-white efflorescences smell strongly of sulfur. 

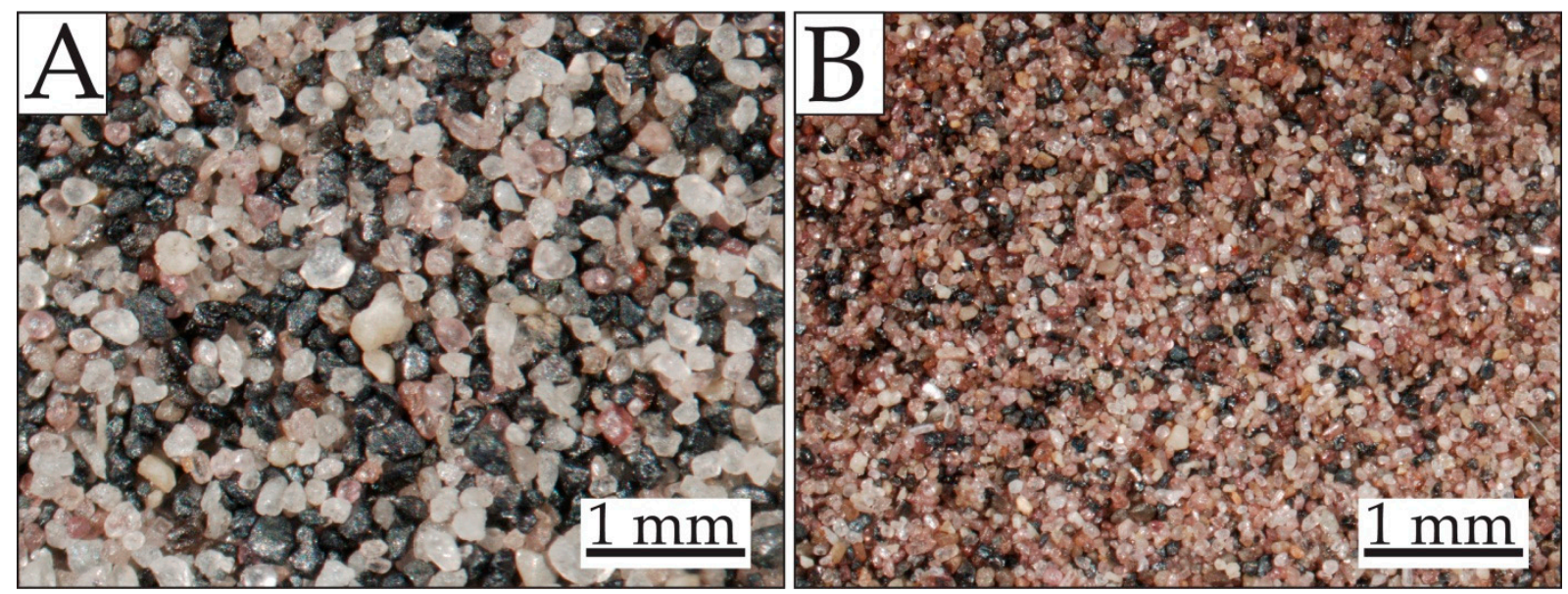

Figure 3. Tailing after the post-processing of cassiterite-bearing sands: (A) tailing from Nyelanding, sample Bngk 4; (B) tailing from Pemali-Bngk 16. Stereoscopic image magn. $\times 2$.

\subsection{Mineral Composition of Tailing}

Examinations of the mineral composition of the tailing revealed its polymineral nature. The content of strategically useful constituents depends much on the sampling site: (1) black samples (more than $50 \mathrm{wt} \%$ ) contain ilmenite $\left[\mathrm{Fe}^{2+} \mathrm{TiO}_{3}\right]$, rutile $\left[\mathrm{TiO}_{2}\right]$ and anatase $\left[\mathrm{TiO}_{2}\right]$, subordinate cassiterite $\left[\mathrm{SnO}_{2}\right]$ (Figure $\left.4 \mathrm{~A}\right) ;(2)$ white-black samples are distinctive by the presence of quartz $\left[\mathrm{SiO}_{2}\right]$, zircon $\left[\mathrm{Zr}\left(\mathrm{SiO}_{4}\right)\right]$, plagioclase, ilmenite, cassiterite, pyrite $\left[\mathrm{FeS}_{2}\right]$, and tourmalines; (3) pink samples (Figures 4 and 5) are composed mainly of zircon, subordinate monazite-Ce $\left[\mathrm{Ce}\left(\mathrm{PO}_{4}\right)\right]$, xenotime- $\mathrm{Y}\left[\mathrm{Y}\left(\mathrm{PO}_{4}\right)\right]$, cassiterite, rutile, and quartz; (4) orange-black samples (Figure 6) are mixtures of monazite-Ce, xenotime-Y, zircon, ilmenite, rutile, and cassiterite (Figure 4B); (5) yellow-black samples contain predominant monazite-Ce and subordinate cassiterite and rutile (Figure 5). On the basis of the predominating mineral constituent (more than $50 \mathrm{wt} \%$ ), four types of tailings were distinguished: (1) zircon; (2) ilmenite-rutile; (3) monazite; and (4) monazite-xenotime-zircon mixture.
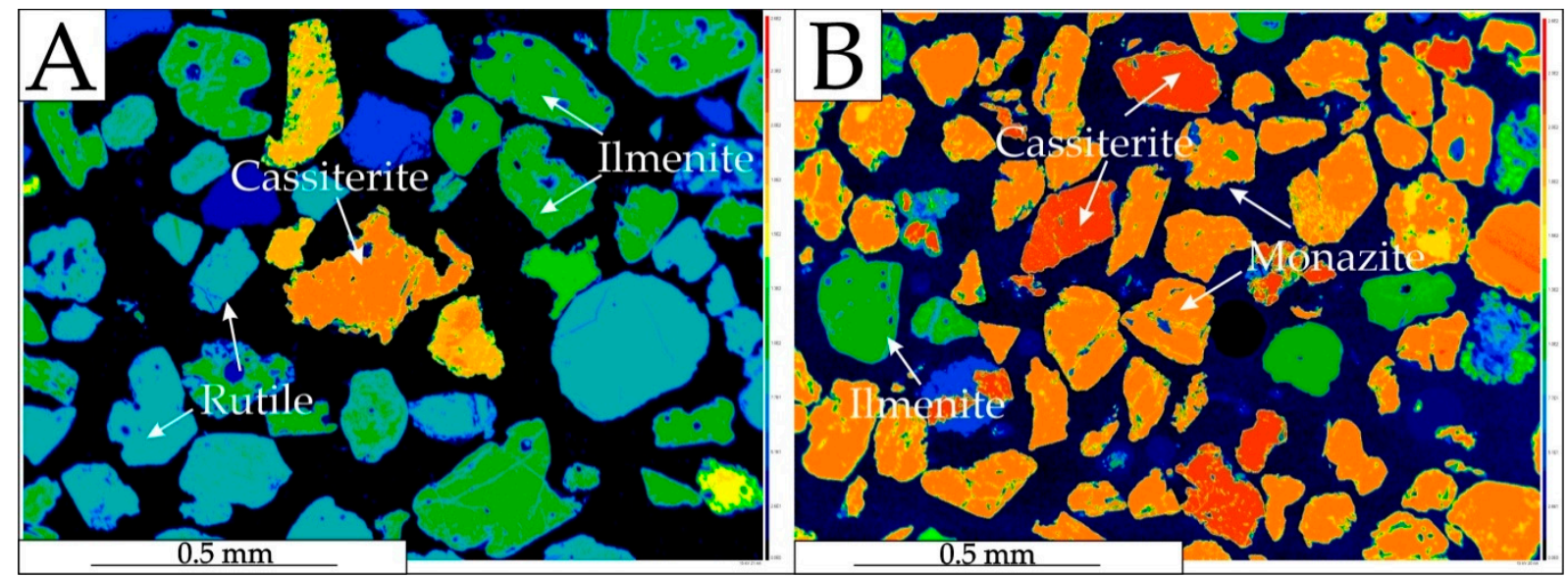

Figure 4. Mapping of minerals using SEM-BSE: (A) Ilmenite-rutile tailing (Sample Bngk 27); (B) monazite tailing (Sample Bngk 21). 


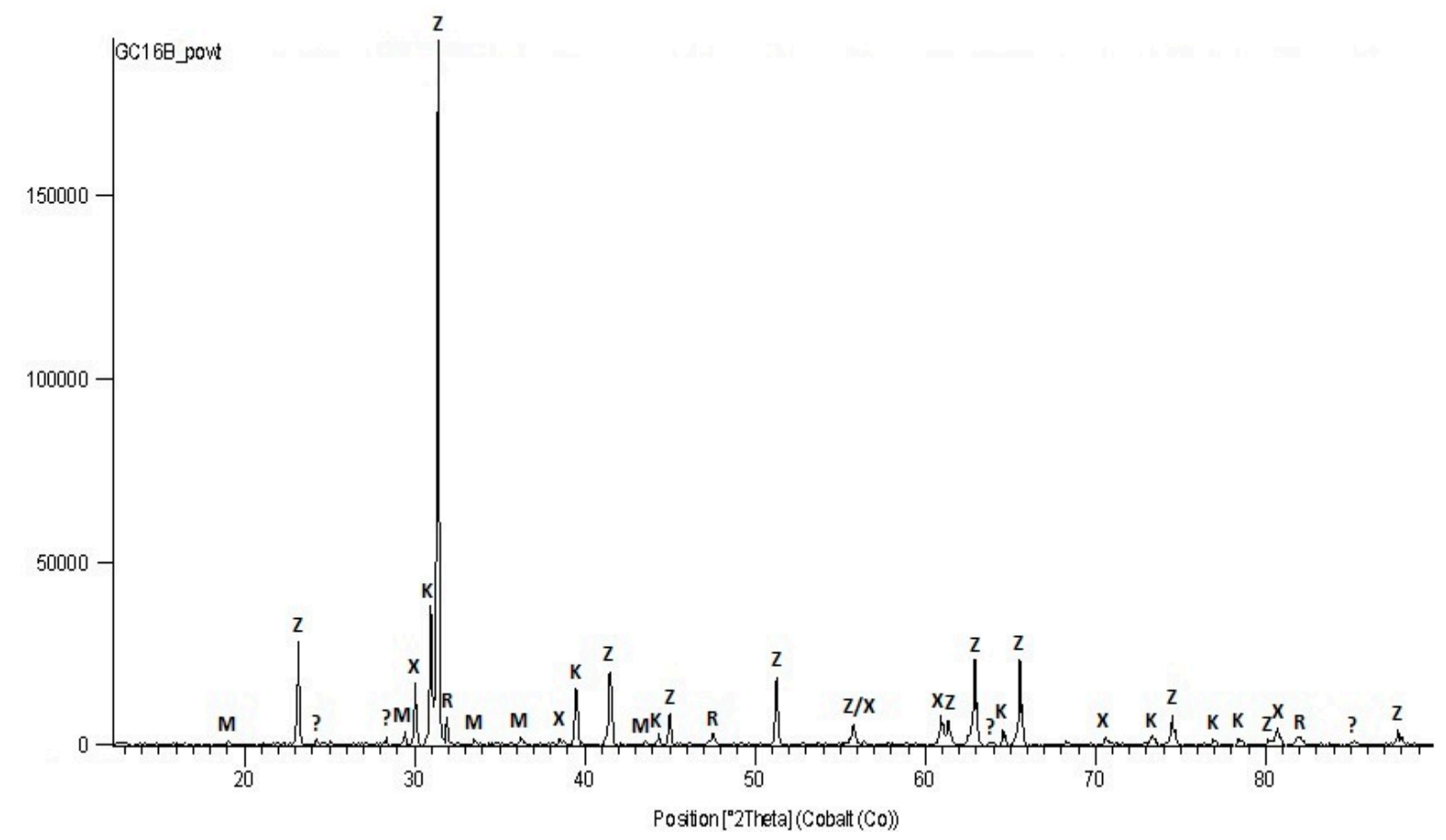

Figure 5. Diffractogram of monazite concentrate. Sample Bngk 25. Z-zircon; M-monazite; X-xenotime; K-cassiterite; R-rutile; ?-unidentified peak, probably Ti-phases.

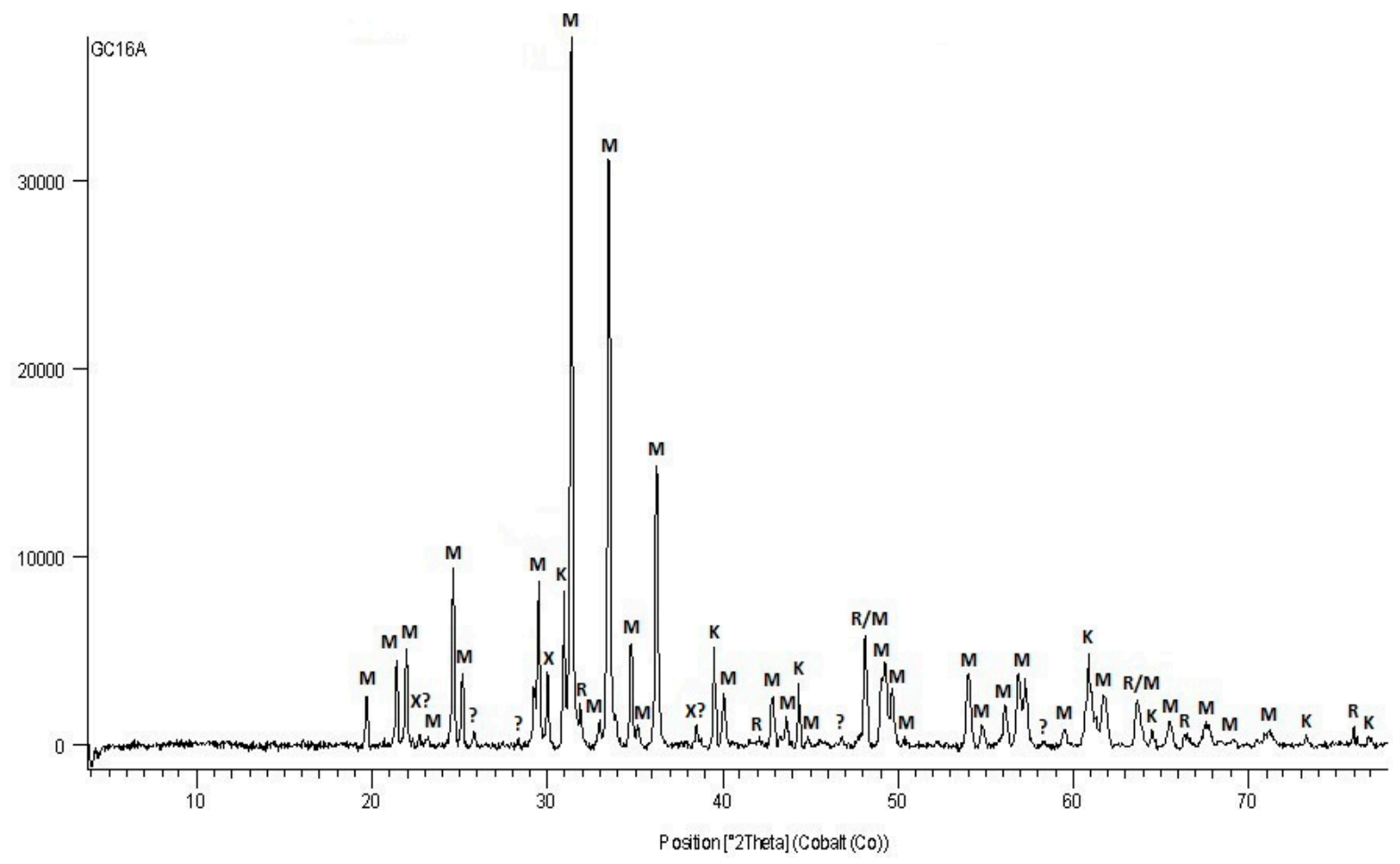

Figure 6. Diffractogram of monazite concentrate (Sample Bngk 21). M-monazite; $\mathrm{X}$-xenotime; $\mathrm{K}$-cassiterite; R-rutile; ?-unidentified peak, probably Ti-phases.

In all the samples examined, subordinate amounts of following minerals have been identified: scheelite $\left[\mathrm{Ca}\left(\mathrm{WO}_{4}\right)\right]$; struverite $\left[(\mathrm{Ti}, \mathrm{Ta}, \mathrm{Fe}) \mathrm{O}_{2}\right]$; columbite $\left[\mathrm{Fe}^{2+} \mathrm{Nb}_{2} \mathrm{O}_{6}\right]$; malayaite $\left[\mathrm{CaSn}\left(\mathrm{SiO}_{4}\right) \mathrm{O}\right]$; polycrase- $(\mathrm{Y})\left[\mathrm{Y}(\mathrm{Ti}, \mathrm{Nb})_{2}(\mathrm{O}, \mathrm{OH})_{6}\right]$; magnetite $\left(\mathrm{Fe}^{2+} \mathrm{Fe}^{3+}{ }_{2} \mathrm{O}_{4}\right)$; topaz $\left[\mathrm{Al}_{2}\right.$ $\left.\left(\mathrm{SiO}_{4}\right)(\mathrm{F}, \mathrm{OH})_{2}\right]$; pyroxenes; amphiboles and copiapite $\left[\mathrm{Fe}^{2+} \mathrm{Fe}^{3+}{ }_{4}\left(\mathrm{SO}_{4}\right)_{6}(\mathrm{OH})_{2} \cdot 20 \mathrm{H}_{2} \mathrm{O}\right]$ form 
ed due to decomposition of pyrite and marcasite. In the mineral concentrate, both individual grains and numerous intergrowths of monazite(-Ce)-xenotime(-Y), quartz-zircon, quartz-tourmaline-cassiterite were noted.

Microscopic observations revealed various forms of minerals: from automorphic zircon crystals to xenomorphic monazites. Monazite and xenotime grains are strongly affected by decomposition processes (Figure 7).

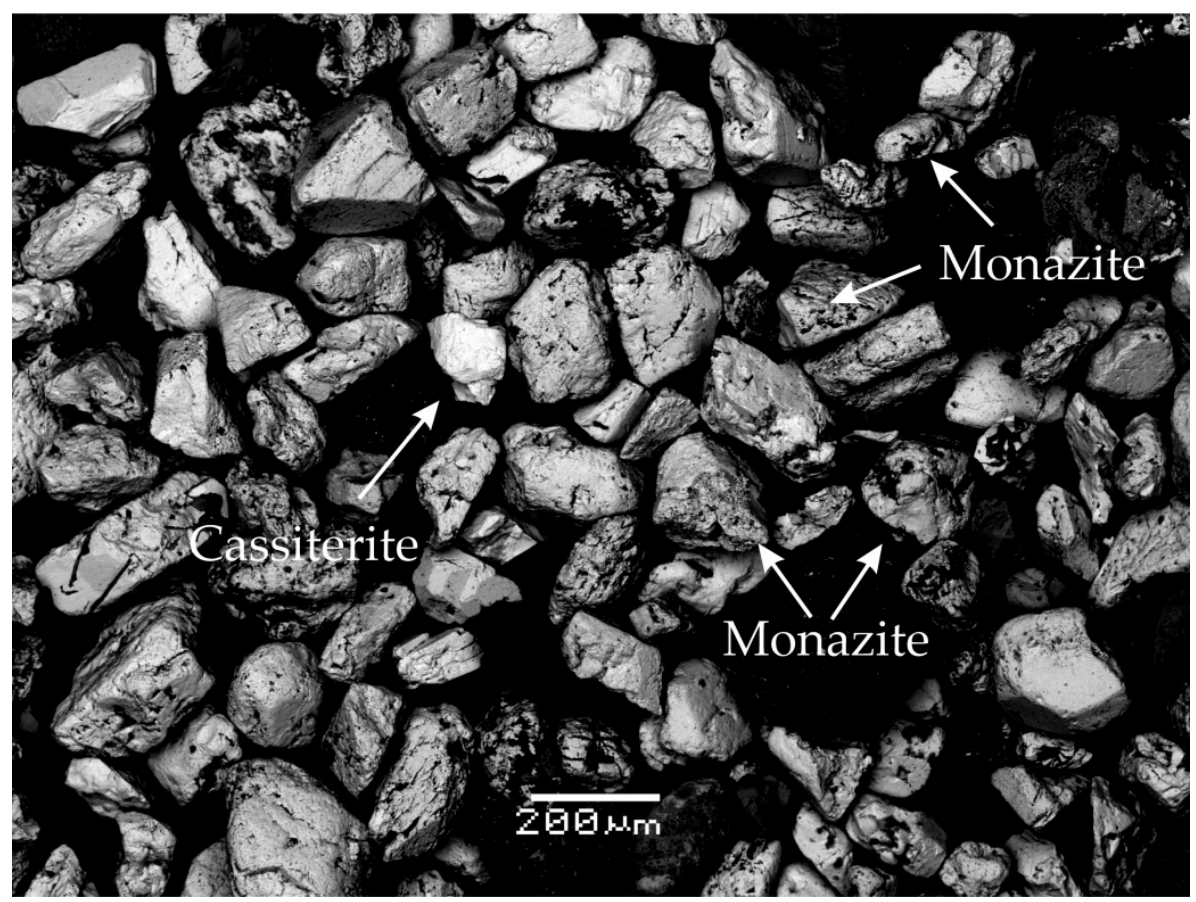

Figure 7. Weathered grains of monazite with numerous traces of dissolution on the grains surface SEM observation.

\subsection{Chemical Composition of Tailing}

Chemical examinations revealed highly differentiated amounts of oxides and metals (Table 1). The $\mathrm{SiO}_{2}$ contents range from 2.81 to $50.36 \mathrm{wt} \%$, and $\mathrm{Al}_{2} \mathrm{O}_{3}$ from 0.40 to $12.80 \mathrm{wt} \%$. Very high values of $\mathrm{Fe}_{2} \mathrm{O}_{3} 4.77-30.40 \mathrm{wt} \%$ and $\mathrm{TiO}_{2} 3.74-48.51 \mathrm{wt} \%$. have been recognized in all samples. The amount of $\mathrm{P}_{2} \mathrm{O}_{5}$ varies from 0.34 to $17.23 \mathrm{wt} \%$, depending on the amount of monazite and xenotime present in the samples. Low values have been found for: $\mathrm{Na}_{2} \mathrm{O}$ (to $1.05 \mathrm{wt} \%$ ), $\mathrm{K}_{2} \mathrm{O}$ (to $0.10 \mathrm{wt} \%$ ), $\mathrm{MgO}$ (to $4.42 \mathrm{wt} \%$; averaging $0.50 \mathrm{wt} \%$ ), $\mathrm{MnO}$ (to $2.46 \mathrm{wt} \%$ ), and $\mathrm{CaO}$ (up to $0.28 \mathrm{wt} \%$ ). The presence of sulfur is related to the presence of pyrite and marcasite but also with their weathering products such as minerals of the copiatite group. Loss on ignition (LOI) is relatively high-from 0.70 to $4.20 \mathrm{wt} \%$. The low TOT/C content is $0.1 \%$ at the maximum which is indicative of a minor amount of organic material in the samples. The TOT/S ranges from 0.03 to $6.12 \%$. The elevated TOT/S is caused by roasting of $\mathrm{FeS}_{2}$. The total amount of oxides falling below $100 \%$ results from the presence of minerals resistant to the melting under the LF202 analysis programs (www.acmelabs.com, accessed on 10 March 2021). 
Table 1. Chemical results of selected tailing samples from Bangka Island. ICP-MS/ES method.

\begin{tabular}{|c|c|c|c|c|c|c|c|c|c|c|c|c|c|c|}
\hline Sample & Bngk2 & Bngk4 & Bngk6 & Bngk7 & Bngk11 & Bngk12 & Bngk13 & Bngk14 & Bngk16 & Bngk18 & Bngk21 & Bngk23 & Bngk25 & Bngk27 \\
\hline Oxide & \multicolumn{14}{|c|}{ in $w t \%$} \\
\hline $\mathrm{SiO}_{2}$ & 26.51 & 20.43 & 47.33 & 20.33 & 50.36 & 31.39 & 14.23 & 3.75 & 17.82 & 25.37 & 2.81 & 27.48 & 18.65 & 32.66 \\
\hline $\mathrm{Al}_{2} \mathrm{O}_{3}$ & 2.00 & 9.41 & 16.18 & 0.40 & 12.80 & 1.15 & 1.64 & 1.34 & 2.67 & 1.89 & 1.16 & 10.14 & 1.00 & 4.64 \\
\hline $\mathrm{Fe}_{2} \mathrm{O}_{3}$ & 14.79 & 19.03 & 12.30 & 4.77 & 12.58 & 12.13 & 16.27 & 30.40 & 21.12 & 15.08 & 5.20 & 15.41 & 11.48 & 13.26 \\
\hline $\mathrm{MgO}$ & 0.20 & 0.16 & 0.40 & 0.03 & 4.42 & 0.13 & 0.03 & 0.05 & 0.11 & 0.17 & $<0.01$ & 0.32 & 0.45 & 0.12 \\
\hline $\mathrm{CaO}$ & 0.06 & 0.03 & 0.14 & 0.05 & 0.02 & 0.06 & 0.02 & 0.02 & 0.03 & 0.06 & 0.28 & 0.11 & 0.05 & 0.04 \\
\hline $\mathrm{Na}_{2} \mathrm{O}$ & 0.08 & 0.35 & 1.05 & 0.01 & 0.05 & 0.04 & 0.01 & 0.01 & 0.06 & 0.07 & 0.02 & 0.66 & 0.02 & 0.17 \\
\hline $\mathrm{K}_{2} \mathrm{O}$ & 0.03 & 0.03 & 0.07 & $<0.01$ & 0.01 & $<0.01$ & $<0.01$ & $<0.01$ & $<0.01$ & 0.02 & $<0.01$ & 0.10 & 0.07 & 0.07 \\
\hline $\mathrm{TiO}_{2}$ & 23.97 & 41.82 & 9.31 & 6.04 & 7.68 & 18.65 & 48.51 & 51.26 & 25.50 & 25.43 & 3.74 & 20.89 & 13.48 & 32.68 \\
\hline $\mathrm{P}_{2} \mathrm{O}_{5}$ & 1.76 & 0.58 & 0.39 & 0.34 & 0.42 & 1.15 & 1.91 & 1.73 & 2.26 & 1.89 & 17.23 & 1.91 & 2.01 & 1.08 \\
\hline $\mathrm{MnO}$ & 1.16 & 1.85 & 0.47 & 0.10 & 0.39 & 0.92 & 1.35 & 2.46 & 1.11 & 1.20 & 0.15 & 1.00 & 0.19 & 0.96 \\
\hline $\mathrm{Cr}_{2} \mathrm{O}_{3}$ & 0.27 & 0.02 & 0.03 & 0.20 & 3.63 & 0.17 & 0.07 & 0.08 & 0.08 & 0.26 & 0.43 & 0.12 & 1.63 & 0.08 \\
\hline LOI & 2.10 & 2.00 & 3.70 & 1.90 & 0.70 & 4.20 & 2.18 & 1.40 & 11.50 & 1.70 & 3.70 & 1.80 & 3.40 & 2.00 \\
\hline Total & 72.94 & 95.78 & 91.41 & 34.17 & 93.16 & 70.02 & 86.21 & 92.58 & 82.25 & 73.17 & 34.77 & 87.76 & 78.36 & 96.10 \\
\hline As & 0.02 & 0.02 & $<0.01$ & 0.03 & 0.02 & 0.02 & 0.02 & 0.02 & 0.02 & 0.03 & 0.23 & 0.03 & $<0.01$ & 0.01 \\
\hline $\mathrm{Pb}$ & $<0.03$ & $<0.03$ & $<0.03$ & 0.07 & 0.05 & $<0.03$ & 0.04 & $<0.03$ & 0.05 & $<0.03$ & 0.06 & $<0.03$ & $<0.03$ & $<0.03$ \\
\hline $\mathrm{Zn}$ & 0.02 & $<0.01$ & 0.06 & 0.01 & 0.03 & 0.03 & 0.01 & $<0.01$ & 0.05 & 0.02 & 0.01 & $<0.01$ & 0.02 & $<0.01$ \\
\hline S & 0.23 & 0.07 & 0.50 & 1.70 & 9.15 & 2.41 & 0.02 & 0.20 & 2.78 & 0.26 & 1.72 & 0.21 & 3.34 & 0.24 \\
\hline TOT/S & 0.40 & 0.08 & 0.69 & 1.69 & 0.03 & 1.76 & 0.04 & 0.20 & 6.12 & 0.25 & 1.65 & 0.22 & 0.96 & 0.23 \\
\hline Element & \multicolumn{14}{|c|}{ in $\mathrm{ppm} / \mathrm{ppb}$} \\
\hline Cd [ppm] & 0.03 & 0.09 & 0.04 & 0.06 & 0.02 & 0.02 & 0.01 & 0.10 & 0.22 & 0.03 & 0.04 & 0.12 & 0.02 & 0.04 \\
\hline $\mathrm{Sb}$ [ppm] & 3.62 & 1.48 & 1.02 & 10.53 & 0.26 & 1.85 & 4.56 & 3.50 & 2.34 & 3.00 & 3.63 & 2.11 & 1.82 & 2.72 \\
\hline $\mathrm{Hg}[\mathrm{ppb}]$ & 169 & 203 & 131 & 188 & 43 & 173 & $\begin{array}{c}3121 \\
\text { in } w t \%\end{array}$ & 439 & 774 & 183 & 426 & 312 & 102 & 432 \\
\hline $\mathrm{Ga}$ & 0.00 & 0.02 & 0.00 & 0.00 & 0.00 & 0.00 & 0.03 & 0.00 & 0.00 & 0.00 & 0.00 & 0.00 & 0.00 & 0.00 \\
\hline Hf & 0.36 & 0.03 & 0.04 & 0.61 & 0.08 & 0.42 & 0.14 & 0.04 & 0.23 & 0.36 & 0.01 & 0.19 & 0.64 & 0.07 \\
\hline $\mathrm{Nb}$ & 0.09 & 0.23 & 0.12 & 0.01 & 0.03 & 0.05 & 0.16 & 0.17 & 0.15 & 0.09 & 0.04 & 0.06 & 0.04 & 0.14 \\
\hline $\mathrm{Ta}$ & 0.01 & 0.02 & 0.08 & 0.00 & 0.01 & 0.01 & 0.01 & 0.01 & 0.01 & 0.01 & 0.02 & 0.03 & 0.01 & 0.02 \\
\hline Sn & 3.89 & 0.50 & 2.96 & 11.64 & 6.72 & 3.98 & 1.58 & 0.87 & 1.03 & 3.68 & 5.89 & 1.23 & 5.14 & 0.83 \\
\hline Th & 0.16 & 0.17 & 0.03 & 0.17 & 0.03 & 0.14 & 0.42 & 0.28 & 0.40 & 0.17 & 1.00 & 0.30 & 0.05 & 0.12 \\
\hline $\mathrm{U}$ & 0.06 & 0.02 & 0.02 & 0.04 & 0.01 & 0.04 & 0.04 & 0.03 & 0.08 & 0.07 & 0.13 & 0.06 & 0.04 & 0.02 \\
\hline W & 0.02 & 0.14 & 0.03 & 0.03 & 0.01 & 0.01 & 0.10 & 0.08 & 0.05 & 0.02 & 0.06 & 0.02 & 0.02 & 0.08 \\
\hline
\end{tabular}


Table 1. Cont.

\begin{tabular}{|c|c|c|c|c|c|c|c|c|c|c|c|c|c|c|}
\hline $\mathrm{Zr}$ & $>5.0$ & 0.90 & 0.90 & $>5.0$ & 2.95 & $>5.0$ & $>5.0$ & 1.15 & $>5.0$ & $>5.0$ & 0.61 & $>5.0$ & $>5.0$ & 2.27 \\
\hline $\mathrm{Sc}$ & 0.01 & 0.01 & 0.01 & 0.01 & 0.00 & 0.01 & 0.01 & 0.01 & 0.01 & 0.01 & 0.01 & 0.01 & 0.01 & 0.01 \\
\hline $\mathrm{Y}$ & 1.05 & 0.27 & 0.24 & 0.46 & 0.17 & 0.40 & 0.49 & 0.50 & 0.51 & 1.20 & 1.10 & 1.06 & 0.57 & 0.44 \\
\hline $\mathrm{La}$ & 0.30 & 0.15 & 0.04 & 0.34 & 0.07 & 0.33 & 0.66 & 0.57 & 0.72 & 0.27 & $>5.0$ & 0.71 & 0.07 & 0.22 \\
\hline $\mathrm{Ce}$ & 0.58 & 0.33 & 0.09 & 0.72 & 0.15 & 0.68 & 1.35 & 1.13 & 1.55 & 0.54 & $>5.0$ & 1.61 & 0.14 & 0.46 \\
\hline $\operatorname{Pr}$ & 0.06 & 0.04 & 0.01 & 0.08 & 0.02 & 0.08 & 0.14 & 0.13 & 0.16 & 0.06 & $>1.0$ & 0.16 & 0.02 & 0.05 \\
\hline $\mathrm{Nd}$ & 0.23 & 0.13 & 0.04 & 0.028 & 0.07 & 0.25 & 0.47 & 0.44 & 0.53 & 0.21 & $>1.0$ & 0.58 & 0.06 & 0.18 \\
\hline $\mathrm{Sm}$ & 0.06 & 0.03 & 0.01 & 0.06 & 0.02 & 0.05 & 0.08 & 0.09 & 0.09 & 0.06 & $>1.0$ & 0.12 & 0.02 & 0.04 \\
\hline $\mathrm{Eu}(\mathrm{ppm})$ & 8.4 & 0.9 & 1.6 & 7.4 & 1.4 & 5.3 & 4.6 & 4.4 & 5.2 & 8.9 & 61.8 & 8.0 & 6.1 & 3.0 \\
\hline Gd & 0.10 & 0.03 & 0.02 & 0.06 & 0.02 & 0.05 & 0.07 & 0.09 & 0.08 & 0.12 & 0.75 & 0.13 & 0.04 & 0.05 \\
\hline $\mathrm{Tb}$ & 0.02 & 0.01 & 0.01 & 0.01 & 0.00 & 0.01 & 0.01 & 0.01 & 0.01 & 0.03 & 0.08 & 0.03 & 0.01 & 0.01 \\
\hline Dy & 0.17 & 0.04 & 0.04 & 0.08 & 0.03 & 0.06 & 0.08 & 0.09 & 0.08 & 0.19 & 0.34 & 0.18 & 0.09 & 0.07 \\
\hline Ho & 0.04 & 0.01 & 0.01 & 0.02 & 0.01 & 0.02 & 0.02 & 0.02 & 0.02 & 0.05 & 0.04 & 0.04 & 0.02 & 0.02 \\
\hline Er & 0.13 & 0.03 & 0.03 & 0.06 & 0.02 & 0.05 & 0.06 & 0.06 & 0.06 & 0.15 & 0.10 & 0.13 & 0.07 & 0.05 \\
\hline $\mathrm{Tm}$ & 0.02 & 0.00 & 0.01 & 0.01 & 0.00 & 0.01 & 0.01 & 0.01 & 0.01 & 0.02 & 0.01 & 0.02 & 0.01 & 0.01 \\
\hline $\mathrm{Yb}$ & 0.14 & 0.03 & 0.04 & 0.06 & 0.03 & 0.05 & 0.06 & 0.05 & 0.07 & 0.15 & 0.07 & 0.14 & 0.08 & 0.05 \\
\hline $\mathrm{Lu}$ & 0.02 & 0.00 & 0.01 & 0.01 & 0.00 & 0.01 & 0.01 & 0.01 & 0.01 & 0.02 & 0.01 & 0.02 & 0.01 & 0.01 \\
\hline$\sum R E E+Y$ & 2.93 & 1.10 & 0.60 & 2.23 & 0.62 & 2.04 & 3.50 & 3.20 & 3.92 & 3.08 & $>15.51$ & 4.93 & 1.20 & 1.66 \\
\hline LREE & 1.23 & 0.67 & 0.20 & 1.47 & 0.32 & .38 & 2.70 & 2.35 & 3.06 & 1.15 & $>13.00$ & 3.18 & 0.29 & 0.95 \\
\hline
\end{tabular}

LREE: La, Ce, Pr, Nd, Sm; HREE+Y: Eu, Gd, Tb, Dy, Ho, Er, Tm, Yb, Lu + Y. 
Tailings contain elevated amounts of the following critical raw materials: Ga (to $0.03 \mathrm{wt} \%$ ); Hf (to $0.64 \mathrm{wt} \%$ ); Ta (to $0.08 \mathrm{wt} \%$ ); W (to $0.14 \mathrm{wt} \%$ ); $\mathrm{Zr}$ (>5.0 wt $\%$ ); and Sc (up to $0.01 \mathrm{wt} \%$ ). Because of the presence melt-resistant minerals, the PF370 (sodium peroxide fusion for refractory mineral ores) procedure was applied. Additionally, high amounts of $\mathrm{Sn}$ to $11.64 \mathrm{wt} \%$ and $\mathrm{Nb}$ to $0.23 \mathrm{wt} \%$ have been found in the samples. The anomalously high REE contents are listed in Table 1. The highest REE values occur in samples with prevailing monazite or monazite with xenotime. In the case of the monomineral Bngk21 sample (more than $90 \mathrm{wt} \%$ of monazite), the REE content is above the upper detection limit $(\mathrm{La}>5 \%, \mathrm{Ce}>5 \%, \operatorname{Pr}>1 \%, \mathrm{Nd}>1 \%, \mathrm{Sm}>1 \%$ ) of the applied LF202 procedure. In sample Bngk 21, the HREE+Y value is $2.51 \mathrm{wt} \%$, including Gd $(0.75 \mathrm{wt} \%), \mathrm{Tb}(0.08 \mathrm{wt} \%)$, Dy $(0.34 w \mathrm{t} \%)$, $\mathrm{Yb}(0.07 \mathrm{wt} \%)$.

In the remaining samples, the high contents of LREE (up to $3.18 \mathrm{wt} \%$ ) and HREE+Y (up to $1.93 \mathrm{wt} \%$ ) also include very high concentrations of the "most critical" HREE: Dy (to $0.18 \mathrm{wt} \%$ ), $\mathrm{Tb}$ (to $0.03 \mathrm{wt} \%$ ), Eu (to $8.4 \mathrm{ppm}$ ), $\mathrm{Nd}$ (to $0.58 \mathrm{wt} \%$ ), and $\mathrm{Y}$ (to $1.20 \mathrm{wt} \%$ ). $\mathrm{LREE} / \mathrm{HREE}+\mathrm{Y}$ ratio ranges from 0.32 to 3.59. An anomalous value of more than 5.17 was noted in sample Bngk 21.

Chemical analyses revealed that potentially toxic metals and metalloids such as As, $\mathrm{Pb}, \mathrm{Cd}, \mathrm{Hg}$ occur within detection limits. Only Sb shows a slightly elevated content attaining $10.53 \mathrm{ppm}$. Large amounts of $\mathrm{U}$ (to $0.13 \mathrm{wt} \%$ ) and Th $(>1.0 \mathrm{wt} \%$ ) were also noted. Monazites (Figure 8A) and xenotime (Figure $8 \mathrm{~B}$ ) observed under the microscope have abundant inclusions, particularly of thorite $\left(\mathrm{ThSiO}_{4}\right)$, and subordinate uranothorite $(\mathrm{Th}, \mathrm{U}) \mathrm{SiO}_{4}$.
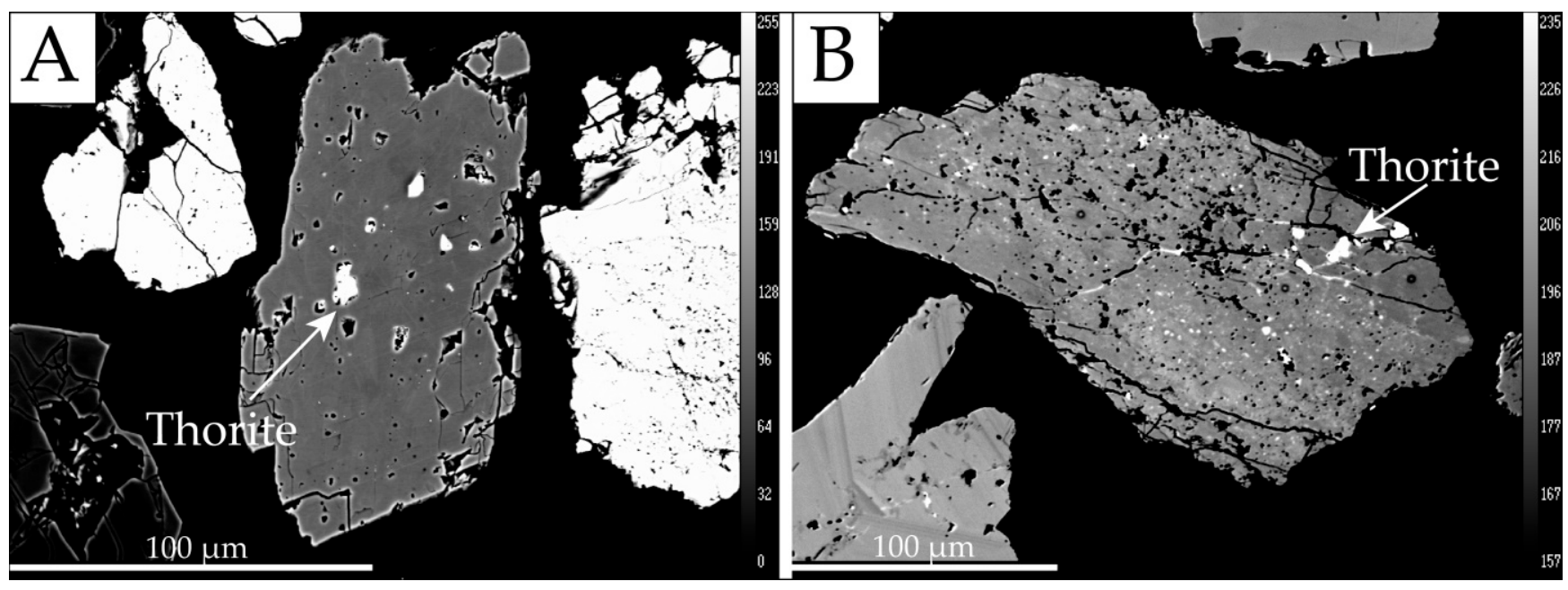

Figure 8. (A) Monazite with thorite inclusions; (B) Xenotime pore space filled with thorite. SEM-BSE observations.

\section{Discussion}

\subsection{Critical and Other Raw Materials from Tailing}

Mining operations connected with exploitation and processing of mineral raw materials are responsible for the generation of waste material stored on dumping sites and in post-flotation settling ponds [32]. Tailings can contain both natural materials such as waste rock and chemically modified matter enriched in organic and inorganic phases [33]. Its composition can be a helpful indicator of possible valuable metals left in parts of the unexploited deposit owing to either a big depth of occurrence, lack of adequate technology, lack of awareness of their occurrence, and their possible economic value at the time of earlier exploitation.

Mining of cassiterite-bearing sands on the Bangka, Belitung, and Singkep Indonesian Tin Islands has been conducted uninterruptedly since the XVIII century [11]. On Bangka Island, two Indonesian government-owned companies are active: PT KobaTin and PT 
Timah. Besides, about 50,000 artisanal small mines (ASM) are likely to operate there, most of them illegally [34]. The fairly dispersed and partly illegal mining means that the total amount of generated tailings is unknown. That produced by small vendors (compradors) is kept on many sites all over the island often on dumping sites adjacent to homes, while that generated by government-owned companies is secured on authorized dumping sites. According to official data available for 2013, the amount of tailing produced by 21 independent smelters is about 28,080 tons. As estimated by Szamałek et al. 2013 [11], the total annual production of tailing from both government-owned companies and compradors on the entire island can exceed $1.2 \mathrm{mln} t$ [11].

Examinations of the tailings from Bangka Island revealed their polymineral nature. In the samples examined, the following anomalous concentrations have been found: REE more than $>15.51 \mathrm{wt} \%, \mathrm{Nb}$ (to $0.23 \mathrm{wt} \%$ ), Ta (to $0.08 \mathrm{wt} \%$ ), $\mathrm{W}$ (to $0.14 \mathrm{wt} \%$ ), $\mathrm{Zr}(>5.0 \mathrm{wt} \%$ ), Sc (up to $0.01 \mathrm{wt} \%$ ), $\mathrm{Ga}$ (to $0.03 \mathrm{wt} \%$ ), and $\mathrm{TiO}_{2}(51.26 \mathrm{wt} \%$ ). The differences in metal contents among the individual samples appear to be related to: (1) the processing technology of cassiterite-bearing sand and (2) the nature of the site of extraction. Schwartz et. al. (1995) [19] noted, that the content of monazite and xenotime in the tailings of Bangka Island may be $1.3 \mathrm{wt} \%$. It was found [11] that tailings could be almost monomineral and contain up to $90 \mathrm{wt} \%$ of monazite. Tailings from the Singkep Island [35], and in particular that from the Kebun Nyjur area, contain up to 5807 ppm REE and are therefore of high economic potential. Their processing and use may, however, be hindered by its high uranium and thorium contents. Indeed, the presence of radioactive mineral phases can make processing of monazite and xenotime economically ineffective owing to the high costs of REO (rare earth oxide) extraction.

The current development of clean technologies and global transformation of the energy sector stimulates the search for new sources of critical raw materials. Tailings from Tin Island may prove an alternative source of high-quality REE concentrates, particularly such as: Dy, Nd, Tb, Eu, Y, and also Ti and Zr concentrates with Hf.

The samples contain high concentrations of $U(0.13 \mathrm{wt} \%)$ and $\mathrm{Th}(>1.0 \mathrm{wt} \%)$. Tailing could be a potential source of natural uranium for the nuclear industry in Europe. In line with the European Commission, the Euratom Supply Agency [36] strives to diversify the supply of natural uranium and nuclear fuel for power and non-power uses. The diversification of supply sources is one of the European strategic objectives for sustainable development, energy and raw materials security. So far, Russia and Kazakhstan are the top providers of natural uranium to the EU in 2019 [36]. To this end, efforts are underway to analyze a new potential source of natural uranium. Studies of imported phosphate rocks indicate the potential recovery of approximately $334 \mathrm{t}$ of natural uranium, with a cut-off at 90 ppm [37]. Tailing from Bangka Island may be a potential source of uranium. A new source of natural uranium could increase Europe's resources security. At the end of 2019, 126 commercial nuclear power reactors were operating in the EU. Euratom Agency estimates of future uranium demand over the period 2030-2039, a reduction in uses of uranium and uranium fuel [36]. Despite this, four reactors were under construction in Europe. In the near future, three nuclear power plants are planned, including in Poland. The development of new projects may contribute to a stable supply of natural uranium for power and non-power uses in Europe.

The use of adequate processing procedures may also enable the recovery of silica, phosphorus, and iron, thereby mitigating the negative impact on the natural environment from mining waste. The high silica percentage (up to $50.36 \mathrm{wt} \%$ ) in the tailings and its suitable physical parameters could also meet the requirements of the glass manufacturing industry. Tailings can be also a cheap and readily available source of quartz sand used in building and chemical industries.

Tailings derived from illegal mining is usually irretrievably lost in as much as they are normally used as fill for space left after mining operations, thereby harmfully affecting the natural environment. Implementation of the zero-waste philosophy and sustainable development may contribute to a better protection of the environment and natural habitats. 
Additionally, circular economy practice can essentially control the local economy by a sound use of mineral raw material. Therefore, tailings processing may prove a good way to increase the income of the local community and thereby enhance development of the artisanal sector.

\subsection{Potential Resources of Critical Raw Materials from Bangka Island}

Granites of Bangka [24], Singkep [38], and Belitung [39] Indonesian Islands are the continuation of the Main Range Granite Province. The Main Range-type granites belong to both type I hornblende monzogranites and type S horblende barren monzogranites. There is no substantial difference either in chemical or isotopic composition when compared with Malaysian granites of the Main Range Granite Province. The Bangka Island granites have been defined as syn-collision and WP granites [24]. According to [39], rocks formed under certain tectonic conditions show elevated REE and Y concentrations. Similar to the Main Range Granite Provence of SW Thailand and West Malaysia, the Bangka Island granites are distinctive by the presence of a tin-tantalum-REE mineralization zone [21] and further examinations confirmed the presence of rich mineralization of the granitoidic rocks [19]. Intensive chemical weathering which continues to affect the granitoidic structures throughout the Neogene till the present is responsible for the formation of colluvial and alluvial slope wash deposits enriched in heavy metals [19].

According to Indonesia's Center of Geological Resources [40], the resources of REE minerals and zircon from the tin mining area are estimated at 951,000 tons [40] and the hypothetical monazite reserves from the Bangka Island coast at 471,087,689 $\mathrm{m}^{3}$ [41]. Presumedly, the REE potential may significantly increase with the progress of geological knowledge of the coastal deposits.

Some mineral potential may be expected in the kaolin covers and their outwash extracted during the development of tin deposits. Superficial covers contain elements such as $\mathrm{Zr}, \mathrm{Hf}, \mathrm{Nb}, \mathrm{Ti}[42,43]$ which show a relatively high resistance to weathering, while others, for example REE, are prone to migration, fractionation and can form considerable enrichments in the weathering profile [44]. The Bangka Island granitoids contain, among others, REE-bearing minerals such as monazites and xenotimes $[18,19]$. Under the microscope, the mineral surfaces show traces of erosion caused by weathering. Both intensive weathering and the presence of numerous kaolin covers may favor concentration of these elements [45]. Washout processes may be the main factor leading to REE concentration in the weathering profile. REE can show strong correlations with clay minerals (kaolinite, haloisite), permitting their adsorption as cations on mineral surfaces [46].

It now seems likely that ion-adsorption deposits will provide the world's largest source of heavy rare earths elements (Gd-Lu) [47]. They originate under subtropical conditions and contain both primary and secondary REE minerals. Favorable climatic conditions, topography, mineral composition of the source rock, and a long exposure to weathering suggest that enrichment in REE metals, mainly HREE, is likely to occur in the kaolin covers of Bangka Island. Exploration for the REE potential should thus focus on the weathering regolith overlying the granitoid structures.

\section{Conclusions}

Distortion of the supply chain of mineral resources caused by the COVID-19 pandemia created an urgent need to look for alternative sources of key raw materials. The REE metals, $\mathrm{Nb}$, Ta form a "metals of the future group", the demand for which will continuously grow. Transformations in the energy sector and progress in modern technologies necessitate a steady and reliable supply of raw materials. The tailings from Bangka Island generated by processing of cassiterite-bearing sands could be seen as a new potential source of critical metals. Mineralogical examinations have confirmed the presence of REE-bearing minerals, ilmenite and rutile, cassiterite, and niobium-tantalum phases. On the basis of the predominating constituent (more than $50 \mathrm{wt} \%$ ), the following concentrates can be distinguished in the tailings: (1) zircon; (2) ilmenite-rutile; (3) monazite; and (4) monazite- 
xenotime-zircon mixture. In all samples, anomalous rare earths elements contents have been found (LREE > $13.00 \mathrm{wt} \%$ ), and HREE+Y (up to $2.51 \mathrm{wt} \%$ ) in particular. Tailing samples contain the most critical HREE: Dy (to $0.34 \mathrm{wt} \%$ ), Tb (to $0.08 \mathrm{wt} \%$ ), Eu (to $61.8 \mathrm{ppm}$ ), $\mathrm{Nd}(>1.0 \mathrm{wt} \%$ ), and Y (to $1.20 \mathrm{wt} \%$ ) and elevated values of: Ga (to $0.03 \mathrm{wt} \%$ ); Hf (to $0.64 \mathrm{wt} \%) ; \mathrm{Ta}$ (to $0.08 \mathrm{wt} \%) ; \mathrm{Nb}(0.23 \mathrm{wt} \%) ; \mathrm{W}$ (to $0.14 \mathrm{wt} \%$ ); $\mathrm{Zr}(>5.0 \mathrm{wt} \%$ ); and Sc (to $0.01 \mathrm{wt} \%)$. These results indicate the tailing to have a high economic potential.

The application of effective technological procedures can be helpful in production of high-quality REE metals concentrates, particularly: Dy, Nd, Tb, Eu, Y; Ti and Zr with Hf. Samples have high content of $U(0.13 \mathrm{wt} \%)$ and $\mathrm{Th}(>1.0 \mathrm{wt} \%)$. Additionally, tailings can be a cheap source of silica, titanium, and phosphorus. Furthermore, a complete utilization of the tailings in accordance with zero-waste philosophy will mitigate the harmful effect from mining waste on the natural environment

Author Contributions: K.Z. conducted field work on Bangka Island; K.Z., K.S. and S.W. conceived the structure of manuscript. K.Z. designed all the figures and wrote the manuscript. K.Z., K.S. and S.W. reviewed and edited the article. All authors have read and agreed to the published version of the manuscript.

Funding: This research was supported by funds from Polish Geological Institute - National Research Institute. No 62.9012.2100.00.0.

Institutional Review Board Statement: Not applicable.

Informed Consent Statement: Not applicable.

Data Availability Statement: Not applicable.

Acknowledgments: Authors would like to express their gratitude towards the reviewers for their useful remarks and comments which allowed the authors to improve this paper.

Conflicts of Interest: The authors declare no conflict of interest.

\section{References}

1. Goodenough, K.M.; Wall, F.; Merriman, D. The rare earth elements: Demand, global resources, and challenges for resourcing future generations. Nat. Resour. Res. 2018, 27, 201-216. [CrossRef]

2. Zhou, B.; Li, Z.; Chen, C. Global potential of rare earth resources and rare earth demand from clean technologies. Minerals 2017, 7, 203. [CrossRef]

3. European Commission. Report on Critical Raw Materials in the Circular Economy; European Commission: Brussels, Belgium, 2018.

4. Galos, K.; Lewicka, E.; Burkowicz, A.; Guzik, K.; Kot-Niewiadomska, A.; Kamyk, J.; Szlugaj, J. Approach to identification and classification of the key, strategic and critical minerals important for the mineral security of Poland. Resour. Policy 2020, 101900. [CrossRef]

5. European Commission. Communication from the Commission to the European Parlament, the Council, the European Economic and Social Committee and the Committee of the Regions. Tackling the Challenges in Commodity Markets and on Raw Materials; 2.2.2011 COM (2011) 25 Final; European Commission: Brussels, Belgium, 2011.

6. European Commission. Communication from the Commission to the European Parlament, the Council, the European Economic and Social Committee and the Committee of the Regions. On the Review of the List of Critical Raw Materials for the EU and the Implementation of the Raw Materials Initiative; 26.5.2014 COM (2014) 297 Final; European Commission: Brussels, Belgium, 2014.

7. European Commission. Communication from the Commission to the European Parlament, the Council, the European Economic and Social Committee and the Committee of the Regions. On the 2017 List of Critical Raw Materials for the EU; 13.9.2017 COM (2017) 490 Final; European Commission: Brussels, Belgium, 2017.

8. European Commission. Communication from the Commission to the European Parlament, the Council, the European Economic and Social Committee and the Committee of the Regions. Critical Raw Materials Resilience: Charting a Path Towards Greater Security and Sustainability; 3.9.2020 COM (2020) 474 Final; European Commission: Brussels, Belgium, 2020.

9. European Commission. Communication from the Commission to the European Parlament, the Council, the European Economic and Social Committee and the Committee of the Regions. The European Green Deal; 11.12.2019 COM (2019) 640 Final; European Commission: Brussels, Belgium, 2019.

10. EuroGeoSurveys. Strategic Research E Innovation Agenda; Draft; EuroGeoSurveys: Brussels, Belgium, 2021.

11. Szamałek, K.; Konopka, G.; Zglinicki, K.; Marciniak-Maliszewska, B. New potential source of rare earth elements. Miner. Resour. Manag. 2013, 29, 59-76. [CrossRef]

12. Grilli, M.L.; Bellezze, T.; Gamsjäger, E.; Rinaldi, A.; Novak, P.; Balos, S.; Piticescu, R.R.; Ruello, M.L. Solutions for critical raw materials under extreme conditions: A review. Materials 2017, 10, 285. [CrossRef] [PubMed] 
13. Edraki, M.; Baumgartl, T.; Manlapig, E.; Bradshaw, D.; Franks, D.M.; Moran, C.J. Designing mine tailings for better environmental, social and economic outcomes: A review of alternative approaches. J. Clean. Prod. 2014, 84, 411-420. [CrossRef]

14. Naicker, K.; Cukrowska, E.; McCarthy, T.S. Acid mine drainage from gold mining activities in Johannesburg, South Africa and environs. Environ. Pollut. 2003, 122, 29-40. [CrossRef]

15. Mehta, N.; Dino, G.A.; Passarella, I.; Ajmone-Marsan, F.; Rossetti, P.; De Luca, D.A. Assessment of the possible reuse of extractive waste coming from abandoned mine sites: Case study in Gorno, Italy. Sustainability 2020, 12, 2471. [CrossRef]

16. Dino, G.A.; Mehta, N.; Rossetti, P.; Ajmone-Marsan, F.; De Luca, D.A. Sustainable approach towards extractive waste management: Two case studies from Italy. Resour. Policy 2018, 59, 33-43. [CrossRef]

17. Mehta, N.; Dino, G.A.; Ajmone-Marsan, F.; Lasagna, M.; Romè, C.; De Luca, D.A. Extractive waste management: A risk analysis approach. Sci. Total Environ. 2018, 622-623, 900-912. [CrossRef]

18. Schwartz, M.O.; Surjono. The Pemali tin deposit, Bangka, Indonesia. Miner. Depos. 1991, 26, 18-25. [CrossRef]

19. Schwartz, M.O.; Rajah, S.S.; Askury, S.K.; Putthapiban, P.; Djaswadi, S. The Southeast Asian Tin Belt. Earth-Sci. Rev. 1995, 38, 95-293. [CrossRef]

20. Metcalfe, I. Permian tectonic framework and paleogeography of SE Asia. J. Asian Earth Sci. 2002, 20, 551-556. [CrossRef]

21. Searle, M.P.; Whitehouse, M.J.; Robb, L.J.; Ghani, A.A.; Hutchison, C.S.; Sone, M.; Wai-Pan Ng, S.; Roselee, M.H.; Chung, S.-L.; Oliver, G.J.H. Tectonic evolution of the Sibumasu-Indochina terrane collision zone in Thailand and Malaysia: Constraints from new U-Pb zircon chronology of SE Asian tin granitoids. J. Geol. Soc. Lond. 2012, 169, 489-500. [CrossRef]

22. Hutchison, C.S.; Taylor, D. Metallogenesis in SE Asia. J. Geol. Soc. Lond. 1978, 135, 405-428. [CrossRef]

23. Cobbing, E.J.; Pitfield, P.E.J.; Darbyshire, D.P.F.; Mallick, D.I.J. The Granites of the South-East Asian Tin Belt. J. Geol. Soc. 1986, 143, 537-550. [CrossRef]

24. Wai-Pan Ng, S.; Whitehouse, M.J.; Roselee, M.H.; Teschner, C.; Murtadha, S.; Oliver, G.J.H.; Ghani, A.A.; Chang, S. Late Triassic granites from Bangka, Indonesia: A continuation of the Main Range granite province of the South-East Asian Tin Belt. J. Asian Earth Sci. 2017, 138, 548-561.

25. Ko, U.K. Preliminary synthesis of the geology of Bangka Island, Indonesia. Bull. Geol. Soc. Malays. 1986, 20, 81-96.

26. Priem, H.N.A.; Boelrijk, N.A.I.M.; Bon, E.H.; Hebeda, E.H.; Verdurmen, E.A.T.; Verschure, R.H. Isotope Geochronology in the Indonesian Tin Belt. Geol. Mijnb. 1975, 54, 61-70.

27. Aleva, G.J.J. The plutonic igneous rocks from Billiton. Indonesia. Geol. Mijnb. 1960, 39, 427-436.

28. Wikarno, U.; Suyatna, D.A.D.; Sukardi, S. Granitoids of Sumatra and the Tin Islands. In Geology of Tin Deposits in Asia and the Pacific, Proceedings of the International Symposium on the Geology of Tin Deposits held in Nanning, Nanning, China, 26-30 October 1984; Hutchison, C.S., Ed.; Springer: Berlin/Heidelberg, Germany, 1984.

29. Ishihara, S. The magnetite-series and ilmenite-series granitic rocks. Min. Geol. 1977, 27, 293-305. [CrossRef]

30. Wentworth, C.K. A scale of grade and class terms for clastic sediments. J. Geol. 1922, 30, 377-392. [CrossRef]

31. Blott, S.J.; Pye, K. GRADISTAT: A grain size distribution and statistics package for the analysis of unconsolidated sediments. Earth Surf. Process. Landf. 2001, 26, 1237-1248. [CrossRef]

32. Lottermoser, B. Mine Wastes. Characterization, Treatment and Environmental Impacts, 3rd ed; Springer: Berlin/Heidelberg, Germany, 2010; pp. 1-400.

33. BRGM. Management of Mining, Quarrying and Ore-Processing Waste in the European Union; European Commision: Brussels, Belgium, 2001; pp. 1-79.

34. Nurtjahya, E.; Franklin, J.; Umroh; Agustina, F. The Impact of tin mining in Bangka Belitung and its reclamation studies. In Applied Technology for Sustainable Environment, Proceedings of the Sriwijaya International Conference on Engineering, Science and Technology (SICEST 2016), Bangka Island, Indonesia, 9-10 November 2016; Iskandar, I., Ismadji, S., Agustina, T.E., Yani, I., Komariah, L.N., Hasyim, S., Eds.; EDP Sciences: Les Ulis, France, 2017; pp. 1-6. [CrossRef]

35. Irzon, R.; Sendjadja, P.; Kurnia; Imtihanah; Soebandrio, J. Kandungan rare earth elements dalam tailing tambang timah di pulau Singkep. J. Geol. Sumberd. Miner. 2014, 15, 143-151.

36. Euratom Supply Agency. Annual Report 2019; Euratom Supply Agency: Luxemburg, 2019; p. 78. [CrossRef]

37. Tulsidas, H.; Gabriel, S.; Kiegiel, K.; Haneklaus, N. Uranium resources in EU phosphate rock imports. Resour. Policy 2019, 61, 151-156. [CrossRef]

38. Soetopo, B.; Subiantoro, L.; Sularto, P.; dan Haryanto, D. The study of monazite and zircon in quarternary rocks in cerucuk belitung. Eksplorium 2015, 33, 25-40.

39. Pearce, J.A.; Harris, N.B.W.; Tindle, A.G. Trace element discrimination diagrams for the tectonic interpretation of granitic rocks. J. Petrol. 1984, 25, 956-983. [CrossRef]

40. Harjanto, S.; Virdhian, S.; Afrilinda, E. Characterization of Indonesia Rare Earth Minerals and Their Potential Processing Techniques. J. Rare Earth. 2013, 52, 99-108.

41. Aryanto, N.C.D.; Kamiludin, U. The Content of Placer Heavy Mineral and Characteristics of REE at Toboali Coast and Its Surrounding Area. Bangka Belitung Province. Bull. Mar. Geol. 2016, 31, 45-54. [CrossRef]

42. Chesworth, W.; Dejou, J.; Larroque, P. The weathering of basalt and relative mobil-ities of the major elements at Belbex, France. Geochim. Cosmochim. Acta 1981, 45, 1235-1243. [CrossRef]

43. Nesbitt, H.W.; Markovics, G. Weathering of granodioritic crust, long-term storage ofelements in weathering profiles, and petrogenesis of siliciclastic sediments. Geochim. Cosmochim. Acta 1997, 61, 1653-1670. [CrossRef] 
44. Nesbitt, H.W. Mobility and fractionation of rare earth elements during weatheringof a granodiorite. Nature 1979, 279, 206-210. [CrossRef]

45. He, B.; Xu, Y.G.; Chung, S.L.; Xiao, L.; Wang, Y. Sedimentary evidence for a rapid, kilometer-scale crustal doming prior to the eruption of the Emeishan flood basalts. Earth Planet. Sci. Lett. 2003, 213, 391-405. [CrossRef]

46. Zhang, Z.; Zheng, G.; Takahashi, Y.; Wu, C.; Zheng, C.; Yao, J.; Xiao, C. Extreme enrichment of rare earth elements in hard clay rocks and its potential as a resource. Ore Geol. Rev. 2016, 72, 191-212. [CrossRef]

47. Estrade, G.; Marquis, E.; Smith, M.; Goodenough, K.; Nason, P. REE concentration processes in ion adsorption deposits: Evidence from the Ambohimirahavavy alkaline complex in Madagascar. Ore Geol. Rev. 2019, 112, 103027. [CrossRef] 